\title{
Solid-State Anaerobic Digestion of Rice Straw for Biogas Production : A Review
}

\author{
Lukhi Mulia Shitophyta ${ }^{1^{*}}$, Budiyono², Ahmad M. Fuadi ${ }^{3}$ \\ ${ }^{1}$ Department of Chemical Engineering, Faculty of Industrial Technology, Ahmad Dahlan University, $3^{\text {rd }}$ \\ Campus, J1. Supomo, Janturan, Yogyakarta 55164 \\ ${ }^{2}$ Department of Chemical Engineering, Faculty of Engineering, Diponegoro University, Jl. Prof. Soedarto, \\ SH, Tembalang, Semarang 50275 \\ ${ }^{3}$ Department of Chemical Engineering, Faculty of Engineering, Universitas Muhammadiyah Surakarta, Jl. A. \\ Yani Tromol Pos 1 Pabelan Kartasura, Surakarta 57102 \\ *email: lukhi.mulia@che.uad.ac.id
}

\begin{abstract}
Biogas is one of the alternative fuels to decrease the consumption of fossil fuel. Raw materials for biogas production can be derived from a wide range of organic wastes including lignocellulosic biomass such as rice straw. Lignocellulosic biomass is abundant and renewable. Biogas production can be processed by solid-state anaerobic digestion. Many factors should be considered on SS-AD, including pretreatment of raw material. Therefore, the purpose of this paper is to provide existing knowledge in SS-AD, factors influencing $S S-A D$, pretreatment of lignocellulosic biomass and identify the preceding researches on the SS-AD.
\end{abstract}

Keywords: biogas, solid-state anerobic digestion, lignocellulose, rice straw

\section{Introduction}

The increase of energy consumption equals to the rise of demand in energy needs, especially for fossil fuels [1]. The amount of oil consumption in the world according to the BP Statical Review of World Energy is 13147.3 million tones in 2015 [2]. On the contrary, global fuel demand increases by around 0.14 million tones per day to attain 15.68 million tones per day in 2035 [3]. In addition, in 2040 the amount of people predicted will reach 9-10 billion that need energy for life [4]. Therefore, the renewable energy is needed to overcome the energy crisis. One of the renewable energy is biogas. Biogas produced by renewable sources. Production of biogas has been started in the previous decades, for instance, in India that have produced biogas since 1950s [5]. The demand of biogas also has a positive rank in the global market [6].

Biogas is a suitable alternative energy in the future, which can reduce environmental impacts, e.g. greenhouse effect, carbon dioxide emission and diminish the dependence on fossil fuel. Biogas can be used as a vehicle fuel, electricity and heat generation [7]. Biogas is a non-polluting gas, smokeless, and blue flame [8]. Biogas consist of $60 \%$ methane, $40 \%$ carbon dioxide, hydrogen sulfide, and trace elements [9]. A variety of organic wastes such as animal dungs, sewage sludge, food wastes, industrial waste water, municipal wastes, including lignocellulosic biomass can be used as raw material of biogas [10,11,12].The plentiful availability of lignocelluloses in the nature makes lignocelluloses gain much interest as feedstock for producing biogas [13]. One of the lignocellulosic biomass, which can be used as a biogas feedstock is rice straw. According to the statistical data, production of rice in Indonesia attained 75.4 million tones in 2015. It was the biggest amount compared with the other agricultural production such as corn, cassava, and peanut [14]. Rice straw consists of $33.4 \%$ cellulose, $28.2 \%$ hemicellulose and $7.4 \%$ lignin [15].

Cellulose and hemicellulose can be converted into biogas [16]. Biogas production consist of pretreatment, hydrolysis and methane production [17]. Biogas production can be generated by either liquid anaerobic digestion (L-AD) or solid-state anaerobic digestion (SS-AD) depending on the total solid content (TS). L-AD is operated on TS content between 0.5 to $15 \%$, while SS-AD operates on the TS content of higher than $15 \%$ [18]. Compare to L-AD, SS-AD has some advantages, like smaller reactor volume, less heating, higher volumetric methane, less wastewater generation relatively stable, and lower total energy loss [19, 20]. However, SS-AD also has the disadvantages e.g. long retention time, poor startup performance and the accumulation of volatile fatty acids [21].

Several factors should be considered on SS-AD are feedstock/inoculum (F/I) ratio, the TS content, $\mathrm{pH}$, etc., including pretreatment of feedstock to make biomass converted easily by microbes. Consequently, the aims of this paper is to highlight knowledge about SS-AD, a little brief about steps of biogas formation, and pretreatment methods for lignocellulosic biomass. 


\section{Stages of Biogas Formation}

Biogas is generated from anaerobic digestion, which involves many different groups of microorganism such as hydrolysing, acidifying, acetogenic and methanogenic bacteria [22]. The general equation of biogas formation is stated in Equation 1 [23].

$$
\begin{aligned}
& \mathrm{C}_{c} \mathrm{H}_{h} \mathrm{O}_{o} \mathrm{~N}_{n} \mathrm{~S}_{s}+y \mathrm{H}_{2} \mathrm{O} \rightarrow x \mathrm{CH}_{4}+(c-x) \mathrm{CO}_{2}+n \mathrm{NH}_{3}+s \mathrm{H}_{2} \mathrm{~S} \\
& x=1 / 8 \cdot(4 c+h-2 o-3 n-2 s) \\
& y=1 / 4 \cdot(4 c-h-2 o+3 n+2 s)
\end{aligned}
$$

Steps of biogas formation comprise of hydrolysis, acidogenesis, acetogenesis and methanogenesis [24]. Sequence of biogas formation can be seen in Figure 1.

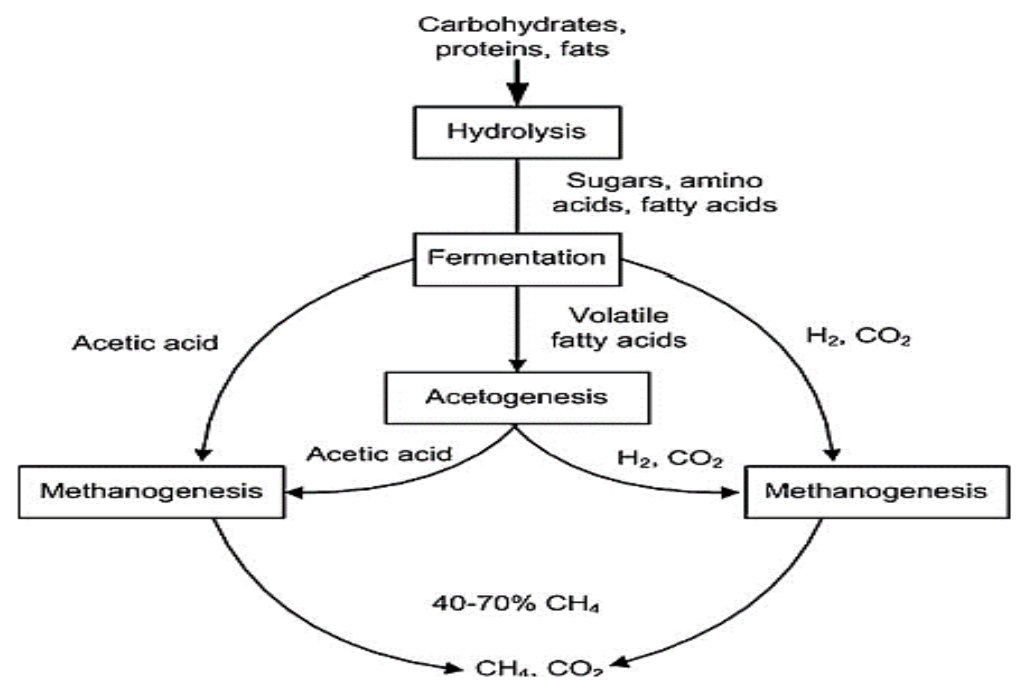

Figure 1. Stages of biogas formation [25]

\section{Hydrolysis}

Hydrolysis is the initial step of anaerobic digestion, which decomposes complex organic materials, like carbohydrates, fats and proteins into simple monomers (glucoses, amino acids and long chain fatty acids). This step involves bacteria which secrete extracellular enzyme to help the breaking of complex molecules into simple molecules [26,27]. Some of hydroloysis bacteria i.e. Peptostreptococcus, Bifidobacterium, Clostridium celerecrescens, Bacteroides ruminicola, Clostridium utyricum, and Clostridium viride [28, 23].

\section{Fermentation(Acidogenesis)}

Acidogenesis step is a process which converts hydrolysis products into hydrogen, short chain fatty acids or volatile fatty acids (propionic acids, butyrate acids, and acetic acids), alcohol and carbon dioxide by acidogenic bacteria [26]. The kinds of acidogenic bacteria are Enterobacterium, Bacteriodes, Acetobacterium and Eubacterium [28].

\section{Acetogenesis}

During this step, acidogenesis products (volatile fatty acids and alcohol) are converted into acetate, hydrogen, and carbon dioxide by Syntrophomonas and Syntrophobacter, while homoacetogenic microorganisms produce acetic acid from hydrogen and carbon dioxide [26,22]. Several of acidogenesis products such as acetate, hydrogen, and carbon dioxide can be consumed directly by methanogens, whereas volatile fatty acids and alcohol will be converted by acetogenic into acetate $[23,29]$.

\section{Methanogenesis}

The last stage of biogas formation is methanogenesis. During this step, methanogens work at anaerobic condition. Methanogens do not degrade all of the substrates. The kind of substrate that can be degraded by methanogens comprises into three groups, namely [23]

$\mathrm{CO}_{2}$ group : $\mathrm{CO}_{2}, \mathrm{HCOO}^{-}, \mathrm{CO}$

Methyl group : $\mathrm{CH}_{3} \mathrm{OH}, \mathrm{CH}_{3} \mathrm{NH}_{3},\left(\mathrm{CH}_{3}\right)_{2} \mathrm{NH}_{2}{ }^{+},\left(\mathrm{CH}_{3}\right)_{3} \mathrm{NH}^{+}, \mathrm{CH}_{3} \mathrm{SH},\left(\mathrm{CH}_{3}\right)_{2} \mathrm{~S}$

Acetic group : $\mathrm{CH}_{3} \mathrm{COO}$ 
The main substrates which utilized by methanogens to produce methane i.e. carbon dioxide, hydrogen, and acetate. However, the other substrate, for instance, methyl amine and alcohol also can be used to produce methane. Methanogens which produce methane from acetate called as acetotrophic methanogens or acetatesplitting methanogens, while methanogens which utilize hydrogen and carbon dioxide to produce methane named as hydrogenotrophs [28,29].

\section{Composition of Rice Straw}

Rice straw is one of the abundant and renewable energy sources in the worldwide due to rice is the staple food for over half of the world's population [30]. Rice straw has 6.59-6.89\% of moisture content, 166.29$194.48 \mathrm{~kg} / \mathrm{m}^{3}$ of bulk density, and $71.21-83.2 \%$ of porosity [31].

\section{Pretreatment of Rice Straw}

Rice straw includes lignocellulosic biomass, which are contained of cellulose, hemicelluloses and lignin. Those components are linked together as a crystallized structure, as a result the degradation of substrate by microorganisms is very hard due their structural complexity [5]. Therefore, pretreatment of rice straw is needed to help microorganisms degrade substrate easily.

1. Mechanical pretreatment

Mechanical pretreatment can be done by cutting rice straw into smaller sizes. Size reduction can break the cell wall [30]. Furthermore, size reduction reduces the degree of polymerization and increases the specific surface area hence it can enrich the total hydrolysis yield [29].

2. Thermal pretreatment

Biomass is heated during this pretreatment. Components of biomass will solubilize if the temperature increases above $150-180^{\circ} \mathrm{C}$ [17]. The thermal pretreament disrupts the chemical bond of the cell wall and membrane [32]. However, thermal pretreatment has negative impacts, i.e. producing phenolic and heterocyclic compounds such as vanilin, vanilin alcohol, furfural and HMF which can be an inhibitory or toxic on methanogens [17].

3. Acid Pretreatment

Acid pretreatment can be performed by concentrated or diluted acids [33]. The acid pretreatment can be carried out either at high temperature and low acid concentration or at low temperature and high acid concentration [24]. Pretreatment using acid hydrolysis can enhance enzymatic hydrolysis [34]. Acid pretreatment with strong acids can solubilize hemicellulose and lignin [29]. However, acid pretreatment has inhibitor products such as acetic acid, furfural, and 5 hydroxymethylfurfural [33].

4. Alkaline pretreatment

Alkaline pretreatment can be done by various alkalis, like sodium hydroxide [35]. Alkaline pretreatment results solubilization, redistribution and condensation of lignin and modification in the crystalline structure of cellulose [17]. Nevertheless, this pretreatment can cause production of inhibitors [29].

5. Oxidative pretreatment

Oxidative pretreatment is carried out by adding an oxidizing compounds, such as hydrogen peroxide or peraacetic acid into the subsrate in order to remove hemicellulose and lignin and increase the accessibility of cellulose [17]. The utilization of oxidative pretreatment has a high risk of inhibitor production [29]. The other disadvantage of oxidative pretreatment is: increasing fraction of carbon dioxide in the biogas [35].

6. Steam Explosion

During this pretreatment, the susbstrate is heated at high temperature, typically between 160 and $220^{\circ} \mathrm{C}$ [35]. The aim of this pretreatment is making substrate more accessible to cellulose attack [33]. The negative impact of steam explosion is formation of inhibitor compounds, such as furfural, HMF, and soluble phenolic compounds, which can disrupt the methane production [17].

7. Biological pretreatment

The Biological pretreatment usually uses microorganism, like brown rot, white rot and soft rot fungi, with white rot are the most effective for biological pretreatment [36]. microorganism can degrade lignin and hemicelluse but in a little fraction of cellulose due to cellulose is more recalcitrant than other components of lignocellulose [24]. The advantages of biological pretreament are able to operate at low temperature without using chemical, low energy requirement and mild operation condition. Nonetheless, the disadvantages of biological pretreatment are slow hydrolysis rate and long residence time [35, 37]. 


\section{Solid-state Anerobic Digestion}

Anaerobic digestion is generally classified into two categories based on the TS content, namely liquidanaerobic digestion (L-AD) and solid-state anaerobic digestion (SS-AD). L-AD operates on the TS content from 0.5 to $15 \%$, while SS-AD is operated on the TS content of higher than $15 \%$ [38]. SS-AD is usually utilized to convert lignocellulosic biomass into biogas. SS-AD has been installed in the Europe since 1990s [39].

SS-AD is an appropriate system for treating lignocellulosic biomass due to the high TS content and low moisture content $[40,11]$. Problems in L-AD, like substrate floating and stratification are not found in SSAD [41]. Biogas production by SS-AD increased 278-357\% compared with L-AD [42]. Besides, methane volume generated by SSAD was 2-7 times higher than L-AD [43]. Several researches on SS-AD have been conducted by using a wide range of lignocellulosic biomass, as shown in Table 2.

Table 2. The previous researches of biogas production by SS-AD

\begin{tabular}{clrc}
\hline No. & \multicolumn{1}{c}{ Substrate } & Methane yield & References \\
\hline 1 & Corn stover, expired dog food & $304.4 \mathrm{~L} / \mathrm{kg} \mathrm{VS}$ & {$[44]$} \\
2 & Spent mushroom substrate and wheat straw & $269 \mathrm{~L} / \mathrm{kg} \mathrm{VS}$ & {$[45]$} \\
3 & Green waste & $524 \mathrm{~L} / \mathrm{kg} \mathrm{VS}$ & {$[46]$} \\
4 & Food waste and green waste & $272.1 \mathrm{~mL} / \mathrm{g} \mathrm{VS}$ & {$[42]$} \\
5 & Switchgrass & $116.9 \mathrm{~L} / \mathrm{kg} \mathrm{VS}$ & {$[43]$} \\
6 & Wheat straw & $66.9 \mathrm{~L} / \mathrm{kg} \mathrm{VS}$ & {$[11]$} \\
7 & Hay and soybean processing waste & $258 \mathrm{~L} / \mathrm{kg} \mathrm{VS}$ & {$[38]$} \\
\hline
\end{tabular}

\section{Factors Affecting SS-AD}

SS-AD must consider several factors for biogas production, as stated below:

1. Temperature

Generally, there are three temperatures in the anaerobic digestion, i.e. pyschrophilic $\left(10-25^{\circ} \mathrm{C}\right)$, mesophilic $\left(25-45^{\circ} \mathrm{C}\right)$, and thermophilic $\left(45-65^{\circ} \mathrm{C}\right)$ [47]. Lower temperatures during the process will reduce methanogen activity. Methanogen will not be active at temperature between 40 and $50^{\circ} \mathrm{C}$ [29]. The ideal temperature for methanogens is around $35-37^{\circ} \mathrm{C}$ in meshophilic digestion. If the temperature drops below the ideal temperature, fermenting microorganisms will be deactivated. As a result, they are not be able to digest all of hydrolysis products. Consequently, the $\mathrm{pH}$ system reduced and the process ceased [28]. On the contrary, higher temperatures cause production of volatile gases which can reduce biogas yield [48].

2. $\mathrm{pH}$

$\mathrm{pH}$ is an important parameter in anaerobic digestion influencing the growth of microorganisms [4]. $\mathrm{pH}$ requirements for each microorganism are different due to various microorganisms in steps of digestion. The optimal $\mathrm{pH}$ for methanogens, i.e. about 6.8-7.6, while the ideal $\mathrm{pH}$ for hydrolysis and acidogenesis between 5.5-6.5 [49]. Methanogens growth will reduce at $\mathrm{pH}$ values from 6 to 8.5 [29]. Reduction of $\mathrm{pH}$ below the optimum $\mathrm{pH}$ causes production of organic acids which can decrease the $\mathrm{pH}$ drastically and cease fermentation step [23]. The $\mathrm{pH}$ value above 8.5 can inhibit digestion process. The increase of $\mathrm{pH}$ values occurred due to ammonia accumulation during degradation of proteins [50]. Methanogens are sensitive to the acid condition and their growth can be inhibited by acidic condition. Therefore, the ideal $\mathrm{pH}$ for anaerobic digestion ranges from 5.5 to 8.5 [26]

3. Carbon to Nitrogen $(\mathrm{C} / \mathrm{N})$ Ratio

$\mathrm{C} / \mathrm{N}$ ratio is denoted as the amount of carbon and nitrogen present in feedstock [24]. An operating $\mathrm{C} / \mathrm{N}$ ratio for anaerobic digestion ranges between 20 to 30 [4,29,25]. The lower $\mathrm{C} / \mathrm{N}$ ratio can result, ammonia accumulation and increase the $\mathrm{pH}$ value beyond 8.5 , whereas the higher $\mathrm{C} / \mathrm{N}$ ratio can decrease biogas production due to rapid consumption of nitrogen by methanogens [18]. Feedstock with low in $\mathrm{C}$ can be mixed by adding materials high in $\mathrm{N}$ to get an optimum $\mathrm{C} / \mathrm{N}$ ratio [4].

4. Total Solids Content (TS)

The TS content affects the pH value, temperature, and efficiency of microorgansim in the digestion process [29]. TS content in the SS-AD system about 20-30\%. A higher TS content can inhibit methanogens activity due to accumulation of organic acids (VFAs) [51]. The TS content higher than $30 \%$ decreases methane production about $17 \%$ [52]. 
5. Feedstock and Inoculum

Substrate (feedstock) converted into methane by microorganisms. The adequate growth of microorganism in anaerobic digestion can be achieved by adding inoculum or nutrient. Microorganisms need an energy source for their activity. The nutrients required for microorganisms, such as carbon, nitrogen, hydrogen, potassium, sulfur, cobalt, copper, iron, nickel, selenium, etc [13]. Feedstock to inoculum ratio (F/I) affects SS-AD system either batch or continue. The SS-AD system in industrial scale has a very low F/I ratio in order to avoid the failure process and maximize the reaction kinetic [53]. The higher F/I ratio can cause overloading of organic [11]. Overloading of organic material can inhibit methanogens and result the failure of digester due to accumulation of organic acids [38].

\section{Conclusions}

Biogas is one of promising renewable energy which can substitute fossil fuels. Solid-state anaerobic digestion is an appropriate method to digest lignocellulosic biomass, such as rice straw into biogas. Since, the recalcitrance of structure of ligocellulose, thus pretreatment is needed to make substrate easily converted by microorganism. The selection of pretreatment must consider several factors, like operational cost, consequences of pretreatment, and effectiveness of pretreatment toward digestion process. Therefore, biogas production by SS-AD must consider the suitable pretreatment method, the paramaters of SS-AD such as temperature, $\mathrm{pH}$, the $\mathrm{C} / \mathrm{N}$ ratio and the $\mathrm{TS}$ content to obtain the optimum biogas yield.

\section{References}

[1] Urmila, G., Sooch, S. S., Jain, A. K. and Gautam, A. 2012. Fabrication and Performance Evaluation of Paddy Straw Based Biogas Digester. International Journal of Engineering Research and Applications, 2(3): 946-949.

[2] -, 2016. BP Statistical Review of World Energy June 2016. http://www.bp.com/statisticalreview, BP p.l.c., July 14,2016

[3] -, 2016. BP Energy Outlook 2016 Edition. http://www.bp.com/energyoutlook, BP p.l.c, 2016

[4] Gashaw, A. 2014. Anaerobic co-digestion of biodegradable municipal solid waste with human excreta for biogas production: A review. American Journal of Applied Chemistry, 2(4): 55-62.

[5] Divya, D., Gopinath, L. R. and Merlin, C. P. 2014. A review on trends issues and prospects for biogas production in developing countries. International Research Journal of Environment Sciences, 3(1): 6269.

[6] Teghammar, A., Forgács, G., Sárvári, I. and Taherzadeh, M. J. 2014. Techno-economic study of NMMO pretreatment and biogas production from forest residues. Applied Energy, 116: 125-133.

[7] NaponKeanoi, KanokornHussaro, and Teekasap, S. 2014. The Effect Of Natural Water With Cow Dung and Agricultural Waste Ratio On Biogas Production From Anaerobic Co-digestion. American Journal of Environmental Science, 9(6): 529-536.

[8] Akwaka, J. C., Kukwa, D. T. and Mwekave, S. S. 2014. Preliminary Study on Co-Digestion of Cow Manure with Pretreated Sawdust for Production of Biogas and Biofertilizer. International Journal of Science and Technology, 3(4): 222-228.

[9] Darwin, Cheng, J. J., Liu, Z., Gontupil, J. and Kwon, O. 2014. Anaerobic co-digestion of rice straw and digested swine manure with different total solid concentration for methane production. Int J Agric \& Biol Eng, 7(6): 79-90.

[10] Tuesorn S, Wongwilaiwalin S, Champreda V, Leethochawalit M, Nopharatana A, Techkarnjanaruk S, et al. 2013. Enhancement of biogas production from swine manure by a lignocellulolytic microbial consortium. Bioresource Technology, 144: 579-586.

[11] Liew, L. N., Shi, J. and Li, Y. 2012. Methane production from solid-state anaerobic digestion of lignocellulosic biomass. Biomass and Bioenergy, 46: 125-132.

[12] Sawatdeenaarunt, C., Surendra, K. C., Takara, D., Oechsner, H. and Kumar, S. $2015 . \quad$ Bioresource Technology Anaerobic digestion of lignocellulosic biomass : Challenges and opportunities. Bioresource Technology, 178: 178-186.

[13] Teghammar, A., 2013, Biogas Production from Lignocelluloses : Evaluation, Dissertation, Chalmers University of Technology, Sweden 
[14] -, 2016, Food Crops. https://www.bps.go.id/, Statistics Indonesia, July 14, 2016

[15] He, Y., Pang, Y., Liu, Y., Li, X. and Wang, K. 2008. Physicochemical Characterization of Rice Straw Pretreated with Sodium Hydroxide in the Solid State for Enhancing Biogas Production. Energy \& Fuels, 22(7): 2775-2781.

[16] Petersson, A., Thomsen, M. H., Hauggaard-nielsen, H. and Thomsen, A. 2007. Potential bioethanol and biogas production using lignocellulosic biomass from winter rye, oilseed rape and faba bean. Biomass and Bioenergy, 31: 812-819.

[17] Hendriks, A. T. W. M. and Zeeman, G. 2009. Pretreatments to enhance the digestibility of lignocellulosic biomass. Bioresource Technology, 100: 10-18.

[18] Yan, Z., Song, Z., Li, D., Yuan, Y., Liu, X. andZheng, T. 2015. The effects of initial substrate concentration, $\mathrm{C} / \mathrm{N}$ ratio, and temperature on solid-state anaerobic digestion from composting rice straw. Bioresource Technology, 177: 266-73.

[19] Zhou, S., Zhang, Y. and Dong, Y. 2012. Pretreatment for biogas production by anaerobic fermentation of mixed corn stover and cow dung. Energy, 46(1): 644-648.

[20] Yang, L., Xu, F., Ge, X. and Li, Y. 2015. Challenges and strategies for solid-state anaerobic digestion of lignocellulosic biomass. Renewable and Sustainable Energy Reviews, 44: 824-834.

[21] Borhan, S., Rahman, S. and Ahn, H. K. 2012. Dry Anaerobic Digestion of Fresh Feedyard Manure : A Case Study in a Laboratory Setting. Int. J. Emerg. Sci., 2(44): 509-525.

[22] Ziemiński, K. and Frąc, M. 2012. Methane fermentation process as anaerobic digestion of biomass : Transformations, stages and microorganisms. African Journal of Biotechnology, 11(18): 4127-4139.

[23] Deublein, D. and Steinhauser, A. 2008. Biogas from Waste and Renewable Resources. Wiley-VCH Verlag GmbH \& Co. KGaA, Weinheim.

[24] Taherzadeh, M. J. and Karimi, K. 2008. Pretreatment of Lignocellulosic Wastes to Improve Ethanol and Biogas Production : A Review. International Journal of Molecular Sciences, 9: 1621-1651.

[25] Li, Y., Park, S. Y. and Zhu, J. 2011. Solid-state anaerobic digestion for methane production from organic waste. Renewable and Sustainable Energy Reviews, 15(1): 821-826.

[26] Kangle, K. M., Kore, S. V, Kore, V. S. and Kulkarni, G. S. 2012. Recent Trends in Anaerobic Codigestion: A Review. Universal Journal of Environmental Research and Technology, 2(4): 210-219.

[27] Yavini, T. D., Taura, U. H., Mohammed, N. and James, M. 2015. Comparative Study of Mesophilic Biogas Production Potentials of Selected Agro-Wastes. The International Journal Of Engineering And Science, 3(2): 1-6.

[28] Schürer, A. and Jarvis, А. 2010. Microbiological Handbook for Biogas Plants. Swedish Waste Management and Swedish Gas Centre

[29] Boontian, N. 2014. Conditions of the Anaerobic Digestion of Biomass. International Journal of Biological, Veterinary, Agricultural and Food Engineering, 66(9): 960-964.

[30] Mussoline, W., 2013, Enhancing The Methane Production From Untreated Rice Straw Using An Anaerobic Co- Digestion Approach With Piggery Wastewater And Pulp And Paper Mill Sludge To Optimize Energy Conversion In Farm-Scale Biogas Plants, Dissertation, University of Paris-Est, Paris, France

[31] Zhang, Y., Ghaly, A. E. and Li, B. 2012. Physical Properties Of Rice Residues As Affected By Variety And Climatic And Cultivation Conditions. American Journal of Applied Science, 9(11): 1757-1768.

[32] Appels, L., Baeyens, J., Degrève, J. and Dewil, R. 2008. Principles and potential of the anaerobic digestion of waste-activated sludge. Progress in Energy and Combustion Science, 34: 755-781.

[33] Sarkar, N., Ghosh, S. K., Bannerjee, S. and Aikat, K. 2012. Bioethanol production from agricultural wastes: An overview. Renewable Energy, 37(1): 19-27.

[34] Gupta, P., Shekhar, R., Sachan, A., Vidyarthi, A. S. and Gupta, A. 2012. A re-appraisal on intensification of biogas production. Renewable and Sustainable Energy Reviews, 16(7): 4908-4916.

[35] Montgomery, L. F. R. and Bochmann, G. 2014. Pretreatment of feedstock for enhanced biogas production. IEA Bioenergy. 
[36] Zheng, Y., Zhao, J., Xu, F. and Li, Y. 2014. Pretreatment of lignocellulosic biomass for enhanced biogas production. Progress in Energy and Combustion Science, xxx: 1-19.

[37] Harmsen, P. F. ., Huijgen, W. J. ., López, L. M. B. and Bakker, R. R. 2010. Literature Review of Physical and Chemical Pretreatment Processes for Lignocellulosic Biomass. Energy Research Centre of the Netherlands, 1-49.

[38] Zhu, J., Zheng, Y., Xu, F. and Li, Y. 2014. Solid-state anaerobic co-digestion of hay and soybean processing waste for biogas production. Bioresource Technology, 154: 240-247.

[39] Li, Y., Zhu, J., Wan, C. and Park, S. Y. 2011. Solid-State Anaerobic Digestion of Corn Stover for Biogas Production. American Society of Agricultural and Biological Engineers, 54(4): 1415-1421.

[40] Brown, D. and Li, Y. 2013. Solid state anaerobic co-digestion of yard waste and food waste for biogas production. Bioresource Technology, 127: 275-280.

[41] Xu, F., Wang, Z. and Li, Y. 2014. Predicting the methane yield of lignocellulosic biomass in mesophilic solid-state anaerobic digestion based on feedstock characteristics and process parameters. Bioresource Technology, 173: 168-176.

[42] Chen, X., Yan, W., Sheng, K. and Sanati, M. 2014. Comparison of high-solids to liquid anaerobic codigestion of food waste and green waste. Bioresource Technology, 154: 215-221.

[43] Brown, D., Shi, J. and Li, Y. 2012. Comparison of solid-state to liquid anaerobic digestion of lignocellulosic feedstocks for biogas production. Bioresource Technology, 124: 379-386.

[44] Xu, F. and Li, Y. 2012. Solid-state co-digestion of expired dog food and corn stover for methane production. Bioresource Technology, 118: 219-226.

[45] Lin, Y., Ge, X. and Li, Y. 2014. Solid-state anaerobic co-digestion of spent mushroom substrate with yard trimmings and wheat straw for biogas production. Bioresource Technology, 169: 468-474

[46] Liu, G., Zhang, R., El-mashad, H. M. and Dong, R. 2009. Bioresource Technology Effect of feed to inoculum ratios on biogas yields of food and green wastes. Bioresource Technology, 100(21): 51035108.

[47] Yu, L., Wensel, P. C., Ma, J. and Chen, S. 2013. Mathematical Modeling in Anaerobic Digestion ( AD ). Bioremediation \& Biodegradation.

[48] Khalid, A., Arshad, M., Anjum, M., Mahmood, T. and Dawson, L. 2011. The anaerobic digestion of solid organic waste. Waste Management, 31(8): 1737-44.

[49] Jha, A. K., Li, J., Nies, L. and Zhang, L. 2011. Research advances in dry anaerobic digestion process of solid organic wastes. African Journal of Biotechnology, 10(65): 14242-14253.

[50] Weiland, P. 2010. Biogas production: current state and perspectives. Appl Microbiol Biotechnol, 85: $849-860$.

[51] Yao, Y., Luo, Y., Yang, Y., Sheng, H., Li, X., Li, T., et al. 2014. Water free anaerobic co-digestion of vegetable processing waste with cattle slurry for methane production at high total solid content. Energy, 74: $309-313$.

[52] Fernandez, J., Perez, M. and Romero, L. I. 2008. Effect of substrate concentration on dry mesophilic anaerobic digestion of organic fraction of municipal solid waste (OFMSW). Bioresource Technology, 99: 6075-6080.

[53] Motte, J.-C., Escudié, R., Bernet, N., Delgenes, J.-P., Steyer, J.-P. and Dumas, C. 2013. Dynamic effect of total solid content, low substrate/inoculum ratio and particle size on solid-state anaerobic digestion. Bioresource Technology, 144: 141-148. 